\title{
ECOLOGICAL STUDY OF FORESTS DOMINATED BY ENDANGERED SPECIES, TAXUS CHINENSIS VAR. MAIREI, IN SHANXI OF CHINA
}

\author{
$\mathrm{RU}, \mathrm{W} .{ }^{1}-$ ZHANG, $\mathrm{J}^{-\mathrm{T}}{ }^{2}{ }^{2}$ \\ ${ }^{1}$ Department of Biology and Chemistry, Changzhi University, Changzhi 046011, China \\ ${ }^{2}$ College of Life Sciences, Beijing Normal University, Beijing 100875, China \\ *Corresponding author \\ e-mail: zhangjt@bnu.edu.cn
}

(Received 22 $2^{\text {nd }}$ October 2009; accepted $5^{\text {th }}$ January 2012)

\begin{abstract}
Taxus chinensis var. mairei is an endemic, endangered and first-class protected tree species with great medicinal values in China. Its forest distributes in very limited region and its area is reducing during the last 30 years. Conservation of this species and its communities is urgent. This study aimed to reveal relationships of T. chinensis var. mairei forests with soil variables and topographic variables in Shanxi of China. Floristic data and environmental data from 95 samples of $10 \mathrm{~m} \times 10 \mathrm{~m}$ in temperate region were analyzed by TWINSPAN, DCA and CCA, and species diversity indices. Eight forest associations were recognized by TWINSPAN and testified by DCA. These associations with special characteristics were main forest types of T. chinensis var. mairei. The results of CCA showed that the vegetation patterns are related to both soil variables and topographic variables. Among the soil variables, soil organic matter, water content, $\mathrm{N}, \mathrm{P}, \mathrm{Zn}$ and $\mathrm{Mn}$ were the most important factors explaining the spatial patterns of forest communities. The topographic variables, elevation, slope and aspect were also significantly correlated with the vegetation. Interactions between the environmental variables were apparent. Species richness, diversity and evenness were significantly related to elevation, but not significantly related to other variables. Further measures for the conservation of $T$. chinensis var. mairei and its forests must be undertaken.
\end{abstract}

Keywords: Forest conservation, protected plant, economic species, quantitative analysis, vegetationenvironment relation, species diversity

\section{Introduction}

Conservation of endangered species and their habitats is a priority feature of environmental policies in many countries and international organizations (Zhang et al., 2007; Oyonarte et al., 2008). Humans have inflicted so much ecological damage on the planet that a real concern is how to protect what remains (Pickett et al., 1997; Larsen and Olsen, 2007). Estimates of current and future extinction rates suggest that we will lose double-digit percentages of the existing species on the Earth in the new century (Pimm \& Askins, 1995). Already, many plant species are listed as endangered (Orians, 1993; World Conservation Monitoring Center, 1992). The China red book of plants lists hundreds of endangered plant species (Fu, 1991).

Plants in genus Taxus produce chemicals of Taxol which is an effective medicinal compound against several cancers. Therefore, species of Taxus are considered as important resource plants in China. There are 5 species in the genus of Taxus Linn. in China. They are T. cuspidate, T. wallichiana, T. mnnanensis, T. chinensis and T. chinensis var . mairei. These species can only be found in mountainous areas in China (Wu, 1979). T. chinensis var. mairei (Lem. \& H. Lev.) W. C. Cheng \& L. K. Fu, a lowgrowing tree species, is an endemic, endangered and first-class nationally protected 
species in China. It is distributed in limited areas of Yunnan, Sichuan, Hubei, Shanxi provinces and Guangxi autonomous district ( $\mathrm{Wu}, 1980)$. However, natural forests dominated by $T$. chinensis var. mairei can only be found in Guangxi, Sichuan and southeastern Shanxi (Ru et al., 2006).

The conservation situation of $T$. chinensis var. mairei and its forest is becoming worsening due to the destruction of natural vegetation and collection of its leaves, branches and even stems and roots for medicines since 1970s, the distribution of this species and its communities have been progressively reduced ( $\mathrm{Fu}, 1991)$. Conservation of this endangered species and its habitats are becoming urgent, and basic studies are needed for its conservation. Despite widespread research on this endangered species, including its taxonomy, chemicals, genetics, reproduction and cultivation (e.g. Wu, 1979; Huo et al., 2007; Jin et al., 2007), study on community ecology of forests dominated by this species is unsatisfactory and needs to be further strengthened (Zhang et al., 2006b). This paper mainly focuses on ecological relations of forests of $T$. chinensis var. mairei and their environmental variables by using multivariate analysis methods. Thus, the objectives of this study were: (1) to identify the community types and analyzing their composition and structure; (2) to elucidate the relationships between forest vegetation and topographic and soil variables, and to find the most important variables to the endangered species and its forests; (3) to define the pattern of species diversity and to interpret the this pattern in relation to environmental variables in the $T$. chinensis var. mairei forests, Shanxi; And (4) Finally, some measures of conservation management for this species and its communities are proposed.

\section{Methods}

\section{Study area}

T. chinensis var. mairei and its forests are distributed in only four counties, Huguan, Lingchuan, Yangcheng and Qinshui, in southeastern Shanxi (Fig. 1).

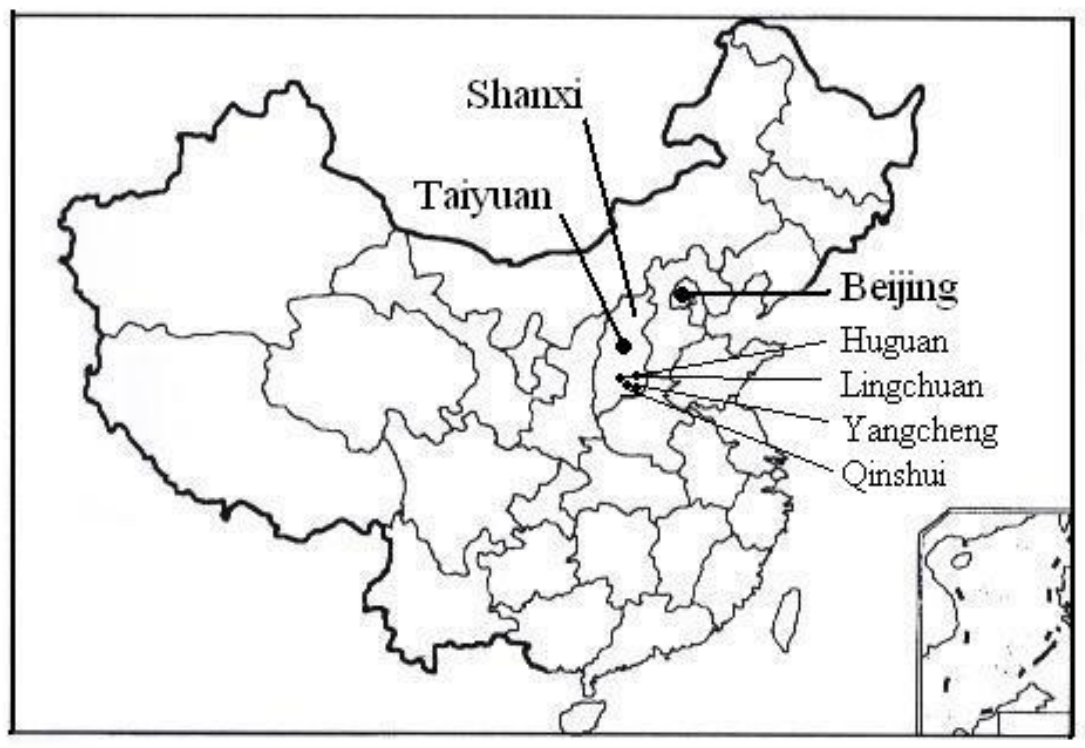

Figure 1. Geographical position of the study sites 


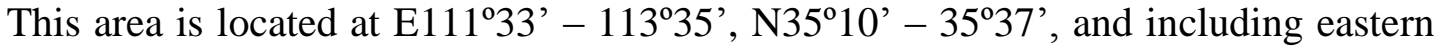
part of Zhongtiao Mountains and southern part of Taihang Mountains. The elevation varies from $600 \mathrm{~m}$ to $1500 \mathrm{~m}$. The climate of this area is warm temperate and semi humidity with continental characteristics and controlled by seasonal wind. The annual mean temperature is $5-13.3{ }^{\circ} \mathrm{C}$, the monthly mean temperatures of January and July are $-5--0.5{ }^{\circ} \mathrm{C}$ and $23-26.1{ }^{\circ} \mathrm{C}$, respectively, and the annual accumulative temperature more than $10{ }^{\circ} \mathrm{C}$ is $2700-3500{ }^{\circ} \mathrm{C}$. The annual mean precipitation varies from $503 \mathrm{~mm}$ to $670 \mathrm{~mm}, 70 \%$ precipitation occurring in July to September within a year. Several soil types, such as cinnamon soil, mountain cinnamon soil, mountain eluviation cinnamon soil and brown forest soil can be found in this area.

\section{Sampling}

Based on a general survey of $T$. chinensis var. mairei species and its communities, five study sites in the four counties were determined (Fig. 1). Ten to thirty-five quadrats of $10 \mathrm{~m} \times 10 \mathrm{~m}$ were established randomly at each site. The number of quadrats at each site was dependent on the area of $T$. chinensis var. mairei forest. The cover, height, basal area, individual number for trees, and the cover, height, abundance for shrubs and herbs were measured in each quadrat. The cover of plants was estimated by eye, and the heights were measured using height-meter for trees and using ruler for shrubs and herbs. The basal diameters of trees were measured using calipers and were used to calculate basal areas. Altogether 128 plant species were recorded in 95 quadrats. Elevation, slope and aspect for each quadrat were also measured and recorded. The elevation for each quadrat was measured by altimeter, the slope and aspect measured by compass meter. Five soil samples of $20 \mathrm{~cm}$ in depth in each quadrat were taken by use of soil cylindered core sampler, and were thoroughly mixed and then one quarter was collected and taken to laboratory for chemical analysis. Soil samples were air-dried and analyzed in laboratory. Soil $\mathrm{pH}$, water content, organic matter, total nitrogen, total phosphorus, $\mathrm{K}$, $\mathrm{Cu}, \mathrm{Mn}, \mathrm{Zn}$ were measured as soil variables. These variables were selected because some of them, such as N, P, K, organic matter, are most important nutrient elements, and some of them, such as micronutrient elements $\mathrm{Cu}, \mathrm{Mn}, \mathrm{Zn}$, are not sufficient in the studied area (Liu, 1992; Ru and Zhang, 2000). A 1:2.5 ratio of soil to distilled water suspension was used to measure $\mathrm{pH}$ using a Whatman $\mathrm{pH}$ sensor meter. Total nitrogen was estimated using Kjeldahl extraction, and total phosphorus was measured via the $\mathrm{HCLO}_{4}-\mathrm{H}_{2} \mathrm{SO}_{4}$ colorimetric method (molybdovanadate method). The organic matter was measured using the method of $\mathrm{K}_{2} \mathrm{Cr}_{2} \mathrm{O}_{7}$ - capacitance. The $\mathrm{K}, \mathrm{Cu}, \mathrm{Mn}, \mathrm{Zn}$ were measured using an Atomic Absorption Spectrophotometer. Water content was measured by oven method.

\section{Data analysis}

We used Importance Value of each species as data in community analysis and calculation of diversity indices. The importance value was calculated by the formulas (Zhang et al., 2006):

IV $_{\text {Tree }}=($ Relative cover + Relative dominance + Relative frequency $) / 3$

IV Scrub and Herbs $=($ Relative cover + Relative height $) / 2$ 
The relative dominance refers to species basal area. The species data matrix is the importance values of 128 species in 95 quadrats.

The environmental data matrix is the values of twelve variables, nine soil factors plus elevation, slope and aspect, in 95 quadrats.

Two-way Indicator Species Analysis (TWINSPAN) (Hill, 1979) for classification, Detrended Correspondence Analysis (DCA) and Canonical Correspondence Analysis (CCA) (ter Braak and Smilauer, 2001) for ordination were used to analyze the variation of communities and their relationships with environmental variables. The calculation of TWINSPAN, DCA and CCA was carried out by computer program of TWINSPAN (Hill, 1979) and CANOCO (ter Braak and Smilauer, 2001) respectively.

Three species diversity indices, one for species richness, one for species diversity, and one for species evenness were used to calculate species diversity in the forests of $T$. chinensis var. mairei. They are

Species number (as a richness index):

$D=S$

Shannon-Wiener diversity index:

$H^{\prime}=-\sum P_{i} \ln P_{i}$

Pielou evenness index:

$E=\left(-\sum P_{i} \ln P_{i}\right) / \ln S$

Where $P_{i}$ is the relative importance value of species $i, P_{i}=N_{i} / N, N_{i}$ the importance value of species $i, N$ the sum of importance values for all species in a quadrat, $S$ the species number present in a quadrat (Pielou, 1975; Zhang, 2004).

The Pearson regression and correlation methods were used to analyze the relationships between species diversity indices and environmental variables.

\section{Results}

\section{Forest communities}

TWINSPAN classified 95 quadrats into 15 clusters at the last division. We chose a standard eigenvalue and got 8 groups, representing 8 associations of $T$. chinensis var. mairei forest. The names of the 8 associations are as follows:

I Assoc. Taxus chinensis var. mairei + Pteroceltis tatarinowii - Sageretia paucicostata + Callicapa japonica var. angustata - Thalictrum squarrosum + Clerodendron trichotomum.

II Assoc. Taxus chinensis var. mairei + Carpinus turczaninowii - Vitex negundo var. heterophylla - Arthraxon lanceolatus.

III Assoc. Taxus chinensis var. mairei + Carpinus turczaninowii - Forsythia suspense + Zanthoxylum planispnum - Carex lanceolata + Potentilla fiagellaris.

IV Assoc. Taxus chinensis var. mairei + Carpinus turczaninowii - Clerodendron trichotomum - Arthraxon lanceolatus + Carex lanceolata.

$\mathrm{V}$ Assoc. Taxus chinensis var. mairei + Carpinus turczaninowii - Viburnum schensianum + Smilax stans-Carex lanceolata + Arthraxon lanceolatus. 
VI Assoc. Taxus chinensis var. mairei + Carpinus turczaninowii - Viburnum schensianum + Cotoneaster multiflorus + Forsythia suspensa - Carex lanceolata + Epimedium grandiflorum.

VII Assoc. Taxus chinensis var. mairei + Carpinus turczaninowii + Fraxinus chinensis - Abelia biflora + Forsythia suspensa + Deutzia discolor - Carex lanceolata.

VIII Assoc. Taxus chinensis var. mairei — Forsythia suspense - Phlomis umberosa.

The structure and environmental characteristics of the eight associations above varied with great similarity (Table 1).

The partitioning of the 95 quadrats in the DCA ordination space conforms closely related to their grouping by TWINSPAN (Fig. 2).

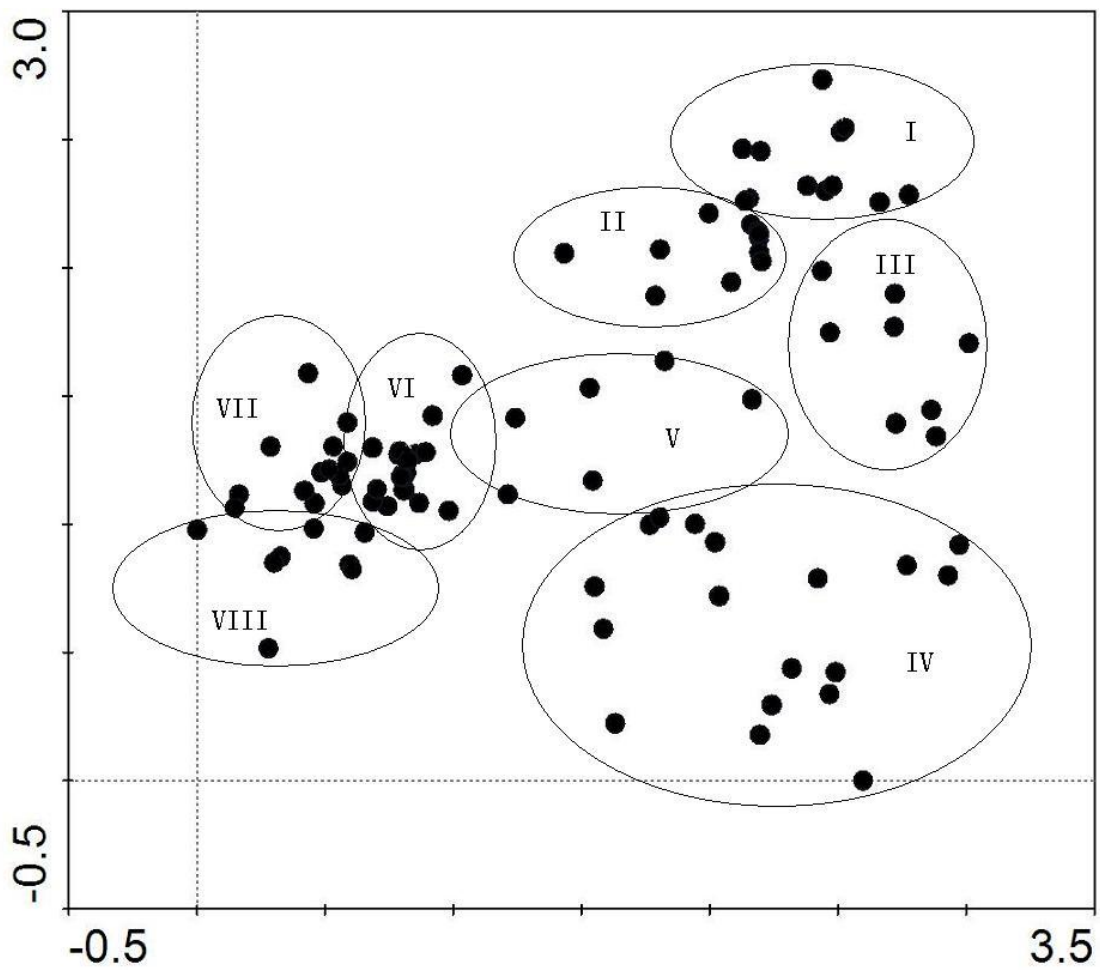

Figure 2. Two-dimensional DCA ordination diagram of 95 quadrats and 128 species in Taxus chinensis var. mairei forests in Shanxi, China. 1, 2, .., 95 representing quadrat number; I, II, ...,VIII representing vegetation associations

The first two DCA axes represent the same gradients represented by the group ordering identified by TWINSPAN. These gradients are comprehensive related to topographical and soil factors. 
Table 1. Structure and environmental characteristics of the eight associations of Taxus chinensis var. mairei forests in Shanxi, China

\begin{tabular}{c|c|c|c|c|c|c|c|c}
\hline $\begin{array}{c}\text { Community } \\
\text { Types }\end{array}$ & $\begin{array}{c}\text { Elevation } \\
(\mathbf{m})\end{array}$ & $\begin{array}{c}\text { Slope } \\
(\boldsymbol{\%})\end{array}$ & Aspect & $\begin{array}{c}\text { Total cover of } \\
\text { community } \\
(\boldsymbol{\%})\end{array}$ & $\begin{array}{c}\text { Cover of } \\
\text { tree layer } \\
(\%)\end{array}$ & $\begin{array}{c}\text { Cover of } \\
\text { mairei } \\
(\%)\end{array}$ & $\begin{array}{c}\text { Cover of } \\
\text { shrub layer } \\
(\%)\end{array}$ & $\begin{array}{c}\text { Cover of } \\
\text { herb layer } \\
(\%)\end{array}$ \\
\hline I & $900-910$ & $5-20$ & $\mathrm{~W}$ & $80-85$ & $50-60$ & $40-55$ & $10-15$ & $15-30$ \\
II & $760-860$ & 15 & $\mathrm{~W}$ & $70-75$ & $40-50$ & $40-50$ & 35 & 20 \\
III & $910-935$ & $15-30$ & $\mathrm{SW}$ & $80-90$ & $55-70$ & $40-50$ & $15-30$ & $60-75$ \\
IV & $730-765$ & $10-15$ & $\mathrm{~W}$ & 80 & $50-60$ & $25-55$ & 15 & $45-60$ \\
V & $910-935$ & $20-35$ & $\mathrm{~N}, \mathrm{NE}$ & $90-95$ & $75-85$ & $40-50$ & $25-35$ & $35-40$ \\
VI & $890-910$ & $10-15$ & $\mathrm{~W}, \mathrm{SW}$ & $85-90$ & $70-80$ & $30-40$ & $30-40$ & $20-30$ \\
VII & $940-950$ & $35-40$ & $\mathrm{SW}$ & $85-90$ & $75-80$ & $40-55$ & $15-25$ & $10-15$ \\
VIII & $910-935$ & $15-35$ & $\mathrm{~S}, \mathrm{SW}$ & 65 & $40-50$ & $30-40$ & $10-25$ & $40-50$ \\
\hline
\end{tabular}

\section{Forests and environments}

In the CCA ordination, the Monte Carlo permutation test indicated that the eigenvalues for the first canonical axis and for the all canonical axes examined were significant $(\mathrm{P}<0.001)$ (ter Braak, 1986). The eigenvalues for the first three axes were $0.348,0.272$ and 0.201 , and species-environment correlations for the first three axes were $0.906,0.868$ and 0.877 respectively (Fig. 3 and Fig. 4).

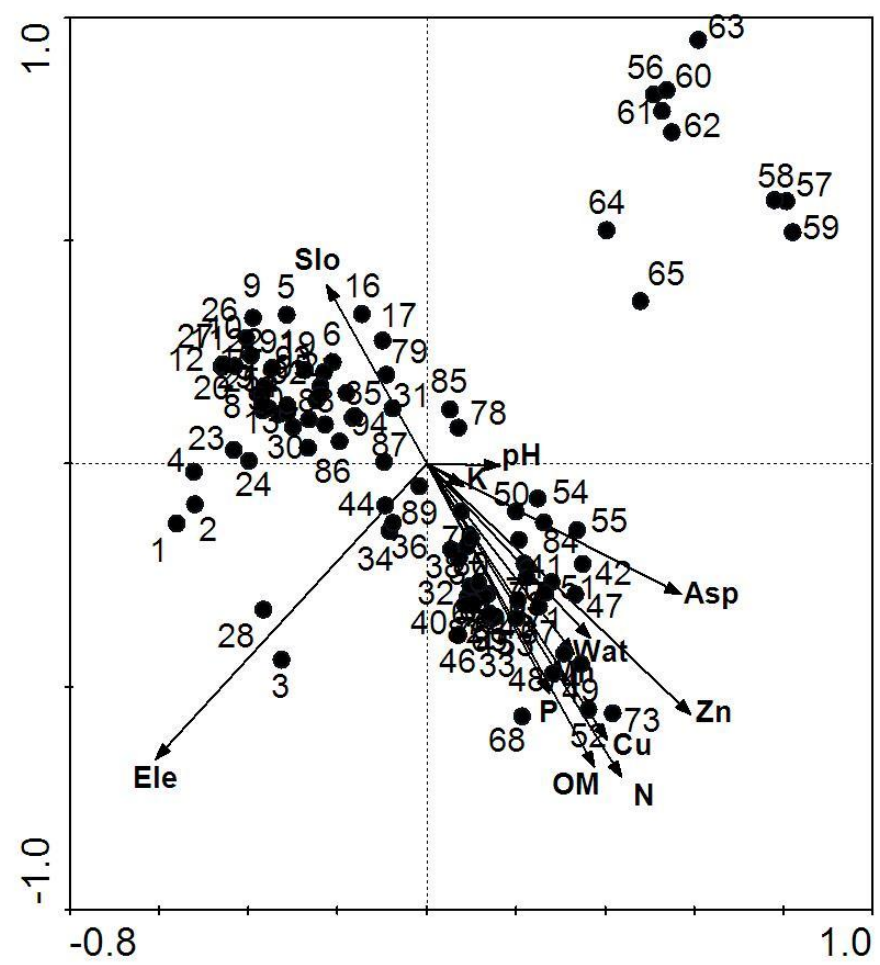

Figure 3. Biplot of 95 quadrats and 12 environmental variables in CCA ordination of Taxus chinensis var. mairei forests in Shanxi, China. Biplot vectors shown represent the major explanatory environmental variables. Ele - Elevation, Slo - slope, Asp - aspect, OM - Soil organic matter content, Wat - soil water content, $\mathrm{pH}-$ soil $\mathrm{pH}$ value; $\mathrm{N}, \mathrm{P}, \mathrm{K}, \mathrm{Mn}, \mathrm{Cu}$ and $\mathrm{Zn}$ were all soil elements 


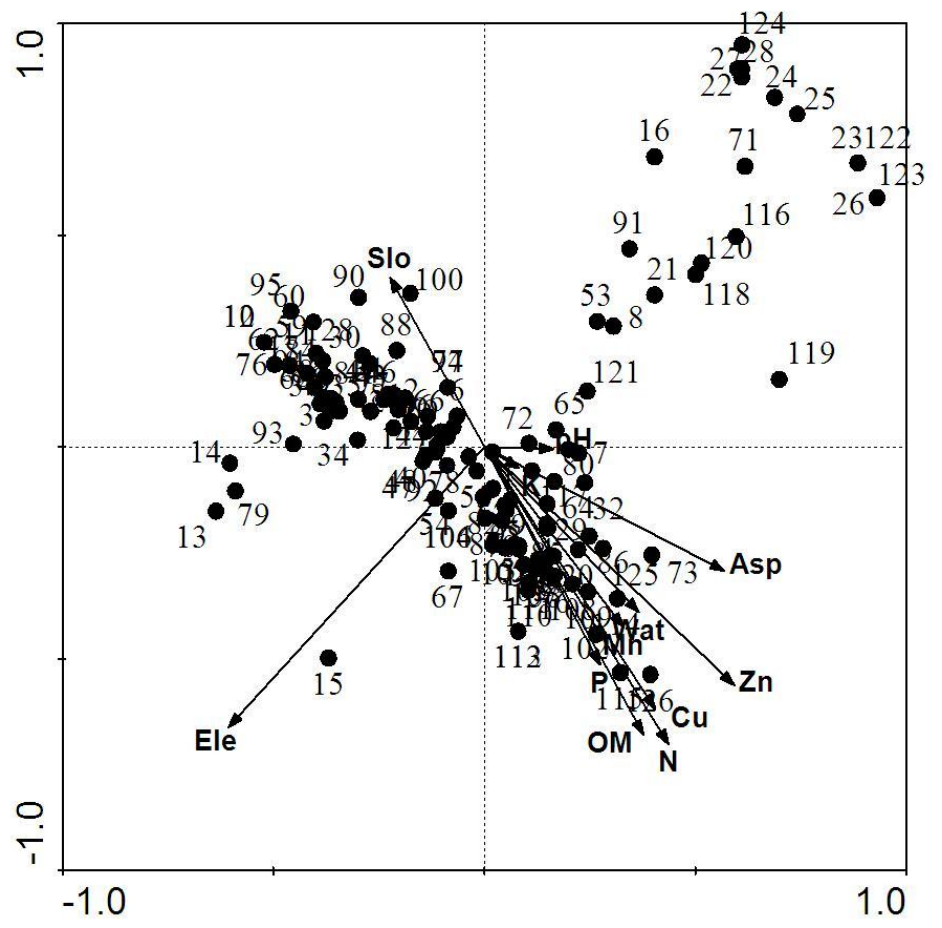

Figure 4. Biplot of 128 species and 12 environmental variables in CCA ordination of Taxus chinensis var. mairei forests in Shanxi, China. Biplot vectors shown represent the major explanatory environmental variables.

Ele - Elevation, Slo - slope, Asp - aspect, OM - Soil organic matter content, Wat - soil water content, $\mathrm{pH}$ - soil $\mathrm{pH}$ value; N, P, K, Mn, Cu and Zn were all soil elements. Species 1 Taxus chinensis var. mairei, 2 Carpinus turczaninowii, 3 Celtis sinensis, 4 Alangium platanifolum, 5 Diospyros lotus, 6 Toxicodendron vernicifluum, 7 Hovenia dulcis, 8 Sorbus puhuashanensis, 9 Fraxinus chinensis, 10 Rhus potaninii, 11 Crataegus kansuensis, 12 Acer grosseri var. hersii, 13 Morus cathayana, 14 Rhus typhina, 15 Cerasu stomentosa, 16 Acer truncatum, 17 Quercus variabilis, 18 Platycladus orientalis, 19 Pinus tabulaeformis, 20 Pteroceltis tatarinowii, 21 Koelrenteria paniculata, 22 Lindera glauca, 23 Idesia polycarpa, 24 Ficus heteromorpha, 25 Tilia mongolica, 26 Carpinus cordata, 27 Pistacia chinensis, 28 Quercus baronii, 29 Juglans cathayensis, 30 Ulmus lamellose, 31 Quercus liaotungensis, 32 Vitex negundo var.heterophylla, 33 Rhamnus parvifolia, 34 Leptodermis oblonge, 35 Lespedza floribumda, 36 Spiraea trilobata, 37 Spiraea pubescens, 38 Lonicera maakii, 39 Lonicera ferdinandii, 40 Forsythia suspense, 41 Cotoneaster multiflorus, 42 Viburnum schensianum, 43 Viburnum hupehense, 44 Deutzia discolor, 45 Abelia biflora, 46 Berchemia floribunda, 47 Smilax scobinicaulis, 48 Smilax stan, 49 Syringa pekinensis, 50

Zanthoxylum planispinum, 51 Grewia biloba var. parviflora, 52 Cotinus coggygris var.pubescens, 53 Clerodendrum trichotomum, 54 Deutzia parviflora, 55 Philadelphus incanus, 56 Callicarpa japonica var.angustata, 57 Sambucus williamsii, 58 Rosa davurica, 59 Euonymus alatus, 60 Schisandra chinensis, 61 Akebia trifoliate, 62 Celastrus orbiculatus, 63 Thalictrum squarrosum, 64 Aster ageratoides, 65 Arthraxon lanceolatus, 66 Carex lanceolate, 67 Elsholzia stauntoni, 68 Elsholzia patrini, 69 Viola collina, 70 Viola acuminate, 71 Viola variegtata, 72 Viola phalacrocarpa, 73 Plectranthus glaucocalyx, 74 Paris verticillata, 75 Phlomis umberosa, 76 Fragaria orientalis, 77 Epimedium brevicornum, 78 Macleaya microcarpa, 79 Mentha haplocalyx, 80 Anemone tomentosa, 81 Polygonatum odoratum, 82 Clematis fruticosa, 83 Goodyera schlechtendaliana, 84 Platanthera chlorantha, 85 Siegesbeckia pubescens, 86 Potentilla fiagellaris, 87 Aquilegia viridiflora, 88 Smilacina japonica, 89 Polygonatum sibiricum, 90 Saussurea japonica, 91 Arisaema erubescens, 92 Vicia unijuga, 93 Pedecularis artselaeri, 94 Ranunculus japonicaus, 95 Atractylodes lancea, 96 Polygonum suffultum, 97 Codonopsis pilosula, 98 Aconitum albo-violaceum, 99 Dryopteris chinensis, 100 Asplenium trichomanes, 101 Dioscorea nipponica, 102 Caryopteris tangu, 103 Asparagus cochinchinensis, 104 Begonia sinensis, 105 Allium senescens, 106 Leonurus pseudomacranthus, 107 Oenathe javanica, 108 Geum aleppicum, 109 Allium ramosum, 110 Fagopyrum tataricum, 111 Oxalis corniculata, 112 Viola chaerophylloides, 113 Carpesium cernllum, 114 Patrinia heterophylla, 115 Torilis japonica, 116 Trachelospermum jasminoides, 117 Euphorbia pekinensis, 118 Cyrtomium fortunei, 119 Girardinia cuspidate, 120

Urtica laetivirens, 121 Selaginella tamariscina, 122 Acalypha australis, 123 Eqisetum ramosisimum, 124 Anemarrhena asphodeloides, 125 Achryanthes bidentata, 126 Cimicifuga foetida, 127 Phytolacca acinosa, 128 Veratrum nigrum 
The canonical eigenvalues indicated separation along the measured environmental gradients. Eleven of the twelve environmental variables were significantly correlated with species and community distribution in Taxus chinensis var. mairei forests (Table 2, Fig. 3, Fig. 4). The dominant environmental variables correlated with the first CCA axis were elevation, aspect and soil Zn. Except for these variables, the slope, soil organic matter, water content, $\mathrm{N}, \mathrm{P}, \mathrm{Cu}$ and $\mathrm{Mn}$ were also significantly correlated with the first CCA axis. The dominant environmental variables correlated with the second CCA axis were elevation, soil organic matter, $\mathrm{N}$ and $\mathrm{Cu}$. Except for these variables, the slope, aspect, soil water content, $\mathrm{P}, \mathrm{Zn}$ and $\mathrm{Mn}$ were also significantly correlated with the second CCA axis. The environmental variables correlated with the third CCA axis were elevation, slope, aspect and soil $\mathrm{pH}$. Soil $\mathrm{K}$ was not significant on any of the first three axes. The canonical coefficients, which represent the regression coefficients between CCA axes and environmental variables produced in the CCA analysis, showed similar relationships of environmental variables with vegetation and species (Table 2).

Table 2. Canonical coefficients and the correlation coefficients of environmental variables with the first three axes of CCA analysis of Taxus chinensis var. mairei forests in Shanxi, China

\begin{tabular}{|c|c|c|c|c|c|c|}
\hline \multirow{2}{*}{$\begin{array}{l}\text { Environmental } \\
\text { variables }\end{array}$} & \multicolumn{3}{|c|}{ Correlation coefficients } & \multicolumn{3}{|c|}{ Canonical coefficients } \\
\hline & Axis 1 & Axis 2 & Axis 3 & Axis 1 & Axis 2 & Axis 3 \\
\hline Elevation & $-0.550^{* * *}$ & $-0.575^{* * *}$ & $0.301^{* *}$ & -0.604 & -0.648 & 0.155 \\
\hline Slope & $-0.202^{*}$ & $0.347^{* * *}$ & $0.499^{* * *}$ & 0.001 & 0.239 & 0.390 \\
\hline Aspect & $0.516^{* * *}$ & $-0.254^{* *}$ & $0.597^{* * * *}$ & 0.444 & 0.086 & 0.772 \\
\hline Water content & $0.331^{* * *}$ & $-0.339^{* * *}$ & $0.212^{*}$ & 0.086 & -0.059 & -0.029 \\
\hline $\mathrm{pH}$ & 0.148 & -0.004 & $-0.221^{*}$ & 0.200 & -0.056 & -0.092 \\
\hline Organic matter & $0.341^{* * *}$ & $-0.589^{* * * *}$ & 0.162 & -0.596 & 0.381 & 0.402 \\
\hline $\mathrm{N}$ & $0.395^{* * *}$ & $-0.609^{* * *}$ & 0.109 & 0.520 & -0.969 & -0.249 \\
\hline $\mathrm{P}$ & $0.248^{*}$ & $-0.446^{* * *}$ & 0.114 & -0.146 & 0.180 & 0.446 \\
\hline $\mathrm{K}$ & 0.075 & -0.044 & 0.152 & -0.013 & 0.066 & 0.119 \\
\hline $\mathrm{Cu}$ & $0.367^{* * *}$ & $-0.537^{* * *}$ & -0.194 & 0.132 & -0.218 & -0.390 \\
\hline $\mathrm{Zn}$ & $0.536^{* * *}$ & $-0.488^{* * * *}$ & 0.052 & 0.594 & -0.210 & -0.340 \\
\hline $\mathrm{Mn}$ & $0.299^{* *}$ & $-0.369^{* * * *}$ & 0.027 & -0.149 & 0.238 & -0.145 \\
\hline
\end{tabular}

Both the soil variables and the topographic variables were significant in affecting the spatial distribution of vegetation and species, because these variables interact and influence each other (Glaser et al., 2000; Zhang, 2002). Soil nutrients, such as N, P, Mn, $\mathrm{Zn}, \mathrm{Cu}$ were significantly correlated with each other, and are related to soil organic matter (Table 3). Most soil variables with obvious effects on plant communities were correlated with aspect and slope. Soil $\mathrm{K}$ and $\mathrm{pH}$ were not correlated with other nutrients. The relationships between topographical variables were not obvious. 
Table 3. Correlation coefficients between environmental variables in Taxus chinensis var. mairei forests in Shanxi, China

\begin{tabular}{l|l|l|l|l|l|l|l|l|l|l|l}
\hline $\begin{array}{l}\text { Environmental } \\
\text { variables }\end{array}$ & Elevation & Slope & Aspect & $\begin{array}{c}\text { Water } \\
\text { content }\end{array}$ & pH & $\begin{array}{c}\text { Organic } \\
\text { matter }\end{array}$ & $\mathbf{N}$ & $\mathbf{P}$ & $\mathbf{K}$ & $\mathbf{C u}$ & $\mathbf{Z n}$ \\
\hline Slope & 0.073 & & & & & & & & & \\
Aspect & 0.130 & 0.031 & & & & & & \\
Water content & 0.064 & 0.088 & $0.384^{* * *}$ & & & & & & \\
pH & -0.088 & $-0.309^{* *}$ & -0.093 & -0.173 & & & & & \\
Organic matter & 0.185 & -0.180 & $0.440^{* * *}$ & $0.544^{* * *}$ & -0.119 & & & & \\
$\mathrm{~N}$ & 0.127 & $-0.201^{*}$ & $0.445^{* * *}$ & $0.596^{* * *}$ & -0.161 & $0.957^{* * *}$ & & & & \\
$\mathrm{P}$ & 0.125 & -0.163 & $0.254^{*}$ & $0.442^{* * *}$ & $-0.203^{*}$ & $0.782^{* * *}$ & $0.747^{* * *}$ & & & \\
$\mathrm{~K}$ & 0.036 & -0.046 & 0.175 & 0.084 & -0.055 & 0.155 & 0.157 & 0.050 & & \\
$\mathrm{Cu}$ & 0.104 & $-0.326^{* *}$ & $0.292^{* *}$ & $0.345^{* * *}$ & -0.170 & $0.595^{* * *}$ & $0.638^{* * *}$ & $0.638^{* * *}$ & 0.130 & \\
$\mathrm{Zn}$ & 0.011 & $-0.229^{*}$ & $0.460^{* *}$ & $0.481^{* * *}$ & -0.116 & $0.873^{* * *}$ & $0.828^{* * *}$ & $0.795^{* * *}$ & 0.120 & $0.709^{* * *}$ \\
$\mathrm{Mn}$ & 0.036 & -0.085 & $0.346^{* * *}$ & $0.454^{* * *}$ & $-0.275^{* *}$ & $0.755^{* * *}$ & $0.792^{* * *}$ & $0.616^{* * *}$ & 0.176 & $0.619^{* * * *}$ & $0.694^{* * *}$ \\
\hline
\end{tabular}

\section{Species diversity in forests}

Species richness, diversity and evenness showed as significant linear relationships with elevation change (Fig. 5). This suggests that elevation is important factor to species diversity in communities of $T$. chinensis var. mairei. Species richness, diversity and evenness are increased with elevation increasing. The relationships between species diversities and other environmental variables were not significant except soil $\mathrm{pH}$ which was related to species evenness (Table 4).

Table 4. Correlation coefficients between species diversity and environmental variables in Taxus chinensis var. mairei forests in Shanxi, China

\begin{tabular}{|c|c|c|c|}
\hline \multirow{2}{*}{$\begin{array}{l}\text { Environmental } \\
\text { variables }\end{array}$} & \multicolumn{3}{|c|}{ Species diversity indices } \\
\hline & $\begin{array}{c}\text { Species } \\
\text { number, } D\end{array}$ & $\begin{array}{c}\text { Shannon-Wiernar } \\
\text { index, } H^{\prime}\end{array}$ & $\begin{array}{c}\text { Evenness index, } \\
E\end{array}$ \\
\hline Elevation & $0.205^{*}$ & $0.360^{* * *}$ & $0.396^{* * *}$ \\
\hline Slope & 0.059 & 0.105 & 0.065 \\
\hline Aspect & 0.067 & 0.036 & 0.042 \\
\hline Water content & 0.039 & 0.048 & 0.032 \\
\hline $\mathrm{pH}$ & 0.024 & 0.160 & $0.295^{* *}$ \\
\hline Organic matter & 0.056 & 0.010 & 0.085 \\
\hline $\mathrm{N}$ & 0.061 & 0.010 & 0.059 \\
\hline $\mathrm{P}$ & 0.064 & 0.010 & 0.114 \\
\hline $\mathrm{K}$ & 0.152 & 0.142 & 0.033 \\
\hline $\mathrm{Cu}$ & 0.109 & 0.066 & 0.039 \\
\hline $\mathrm{Zn}$ & 0.132 & 0.109 & 0.010 \\
\hline $\mathrm{Mn}$ & 0.092 & 0.045 & 0.067 \\
\hline
\end{tabular}



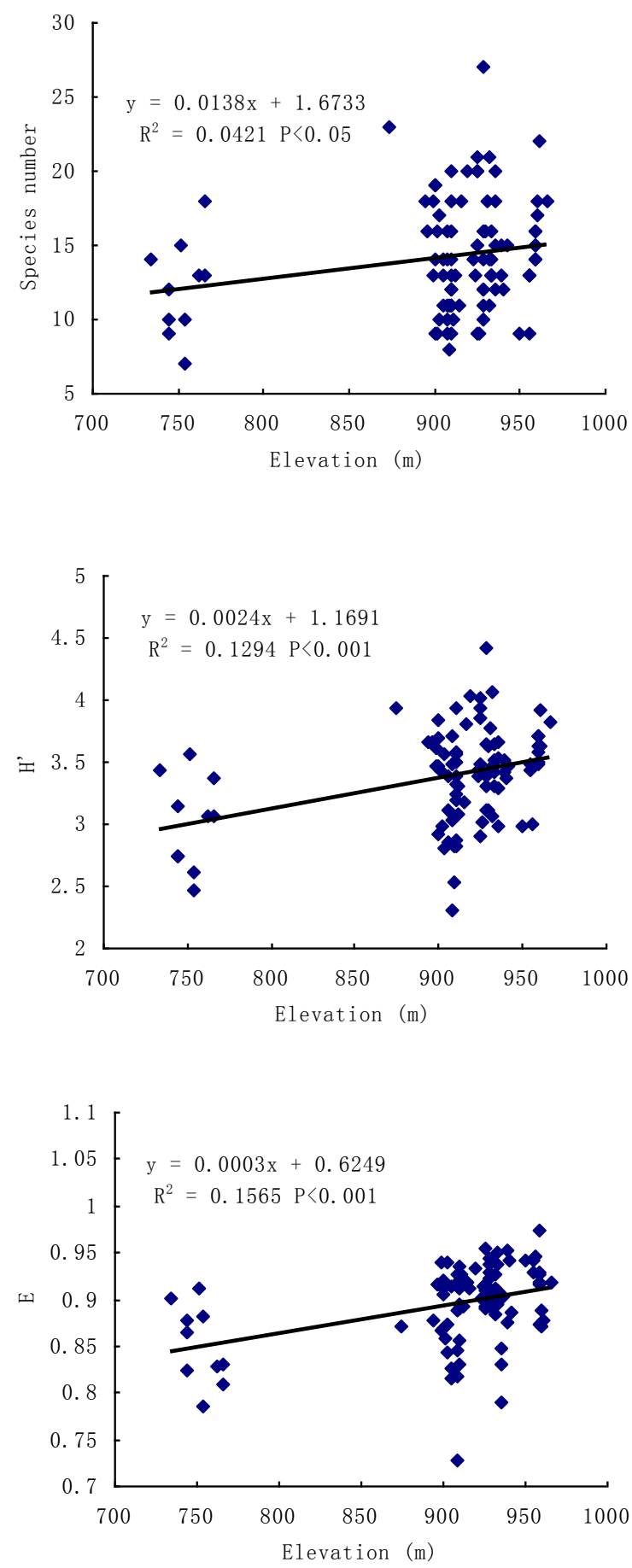

Figure 5. The variation of species richness, diversity and evenness along the elevation gradient in Taxus chinensis var. mairei forests in Shanxi, China. The H' refers to the Shannon-Wiener index and $E$ to evenness index 


\section{Discussion}

T. chinensis var. mairei forests in the study area varied in composition and structure. TWINSPAN successfully distinguished them into different forest associations. The eight associations represent the general forest types of T. chinensis var. mairei in warmtemperate area in China (Wu, 1980; Zhang et al., 2006a). They are almost all secondary natural forests. The classification scheme of forest communities is reasonable according to the Chinese vegetation classification system (Wu, 1980; Ma, 2001). The composition of tree layers of these associations is simple and very similar to each other. Taxus chinensis var. mairei, Pteroceltis tatarinowii and Carpinus turczaninowii are codominant species in these associations, and their difference is the proportion of these three species (Zhang et al., 2006b). The shrub layers and herb layers of associations varied greatly, and the dominant species and composition of shrubs and herbs played important roles in community differentiation (Zhang and Chen, 2007). The results of TWINSPAN were proved by DCA analysis. Each association had its own distribution area in the DCA space, and their ordination was related to environmental gradients. The DCA axes were comprehensive gradients of topographical and soil factors (Zhang, 2004).

The environmental factors are important to plant growth and vegetation development (Brunner et al., 1999; Liu, 1992; Molles, 2002). CCA analysis indicated that topographical and soil variables were significant to T. chinensis var. mairei forests in warm-temperate area (Zhang, 2005). Among topographic variables, elevation was the most important factor in relation to vegetation distribution pattern. This is mainly due to the changes of precipitation and soil moisture along altitudinal gradient, i.e. precipitation and soil moisture are improving with the elevation increasing. Precipitation is a limiting factor to plant growth and distribution in this area (Zhang et al., 2006a; Zhang and Chen, 2004). Beside elevation, slope and aspect were also significant to spatial variation of $T$. chinensis var. mairei communities in the study area. The variation of elevation, slope and aspect also affects the change of soil variables (Anderson, 1982; Molles, 2002, Paschke et al., 2003; Saeki, 2007).

The soil nutrients are key factors to plant growth and vegetation development and the importance of nutrient factors in a community or a region depends on their amount and distribution (Brunner et al., 1999; Saarsalmi et al., 2001; Oyonarte et al., 2008). Among soil variables analyzed, the organic matter, $\mathrm{N}$ and $\mathrm{Cu}, \mathrm{P}$, and $\mathrm{Zn}$ were greatly correlated with community distribution and variation. Except for these variables, soil water content and $\mathrm{Mn}$ were also related to the forest variation. Some of these factors were the most important nutrients and some of them were distributed unevenly in the area of $T$. chinensis var. mairei community distribution (Liu, 1992; Ma, 2001). The soil organic matter was significant to vegetation distribution, for many nutrients were related to organic matter in soils (Wu, 1980; Zhang and Oxley, 1994), and the accumulation and amount of organic matter were strongly related to temperature and moisture in soils (Anderson, 1982; Wu, 1980; Zhang, 2002). For micronutrients in soils, community variation was more significantly related to $\mathrm{Mn}$ and $\mathrm{Zn}$, this is due to that the spatial distribution of these two elements are uneven, and they were not sufficient in some communities (Ertli et al., 2004; Zhang et al., 2006b). Soil water content was significant because precipitation was a limiting factor to plant growth and vegetation distribution, and it was significant to nutrient efficiency (Anderson, 1982; Zhang, 2002; Fosaa, 2004). The effects of soil $\mathrm{K}$ and $\mathrm{pH}$ on $T$. chinensis var. mairei communities were not apparent, because their variations among associations were small. This is identical to 
the results of some woodland and grassland soil studies in this area (Ma, 2001; Zhang et al., 2006b).

All the ecological factors coexist and act on plants and vegetation simultaneously in communities and ecosystems (Molles, 2002). These factors, including topographic variables, soil variables and human activities, interact with each other, and this interaction is very complicated. In our study, the most important nutrients, soil organic matter, water content, N, P, Zn and Mn were significantly correlated with each other (Paschke et al., 2003; Jin et al., 2007). The most soil variables were correlated with aspect, and some of them related to slope, i.e. the variation of aspect and slope affects other environmental variables that further influence plants and vegetation (Bergmeier, 2002; Fosaa, 2004). The topographical variables were not significantly correlated with each other which may be due to their small variations in $T$. chinensis var. mairei forests (Zhang and Zhang, 2007; Ru et al., 2006).

Species richness, diversity and evenness were all shown as a significant linear relation with elevation in the $T$. chinensis var. mairei forests. This is consistent with many other studies of forests (Stevens, 1992; Lomolino, 2001; Zhang et al., 2006b). They were increased with increasing elevation, which is mainly due to the improvement of water-conditions and nutrients along the altitude gradient (Zhang and Zhang, 2007). Species richness, diversity and evenness were not significantly related to other environmental variables except elevation in the studied communities, which is an exception of mountain vegetation studies (Zhang et al., 2006b; Zhang and Chen 2007). In Lishan Reserve and Taihang Mountain, species richness, diversity and evenness were significantly correlated with soil organic matter and nutrients (Zhang et al., 2006b; Zhang and Zhang, 2007). T. chinensis var. mairei forests distributed in the lower area $(730-950 \mathrm{~m})$ with comparatively poor soil, and the forest structure, composition, diversity and its soil were all under development (Ma, 2001; Ru et al., 2006). Therefore, the interaction patterns of species diversity with environmental variables were different from that in mature communities (Anderson, 1982; Zhang et al., 2006).

For conservation of $T$. chinensis var. mairei and its forests, one natural reserve should be established in the studied region, which must be effective in controlling cutting for medicine and other interferences (Huo et al., 2007; Sajwan and Kala, 2007; Zhang et al., 2007). In the reserve, planting T. chinensis var. mairei sapling in suitable communities can increase its cover and density, which can accelerate the development and regeneration of the forests (Sun et al., 2007; Zhang and Chen, 2007). Additionally, soil fertilization should be used for young plantations to improve the living conditions which are effective in enriching species composition and diversity ( $\mathrm{Ru}$ et al., 2006; Jin et al., 2007).

Acknowledgements. The study was financial supported by the National Natural Science Foundation of China (Grant No 30870399).

\section{REFERENCES}

[1] Anderson, J.P.E. (1982): Soil respiration. - In: Page, AL. (ed.) Methods of soil analysis, chemical and microbiological properties, Part 2. Madison: American Society of Agronomy, 831-871.

[2] Bergmeier, E. (2002): The vegetation of the high mountains of Crete: A revision and multivariate analysis. - Phytocoenologia 32(2): 205-249. 
[3] Brunner, I., Rigling, D., Egli, S., Blaser, P. (1999): Response of Norway spruce seedlings in relation to chemical properties of forest soils. - Forest Ecology and Management 116(1-3): 71-81.

[4] Ertli, T., Marton, A., Foldenyi, R. (2004): Effect of $\mathrm{pH}$ and the role of organic matter in the adsorption of isoproturon on soils. - Chemosphere 57(8): 771-779.

[5] Fosaa, A.M. (2004): Biodiversity patterns of vascular plant species in mountain vegetation in the Faroe Islands. - Diversity and Distributions 10(3): 217-223.

[6] Fu, L.G. (1991): The red book of plants of China. - Science Press, Beijing.

[7] Glaser, B., Turrion, M-B., Solomon, D., Ni, A., Zech, W. (2000): Soil organic matter quantity and quality in mountain soils of the Alay Range, Kyrgyzia, affected by land use change. - Biology and Fertility of Soils 31(5): 407-413.

[8] Hill, M.O. (1979): TWINSPAN-A Fortran program for arranging multivariate data in an ordered two-way table by classification of the individuals and atributes. - Ithaca, Cornell University.

[9] Huo, C.H., Wang, Y.F., Zhang, X.P. (2007): A new metabolite with a new substitution pattern from the seeds of the Chinese yew, Taxus mairei. - Chemistry \& Biodiversity 4: 84-88.

[10] Jin, G-Q., Yu, Q-G., Jiao, Y-L. (2007): Effects of combined fertilization on young growth of Taxus chinensis var. mairei. - Forest Research 20(2): 251-256.

[11] Larsen, H.O., Olsen, C.S. (2007): Unsustainable collection and unfair trade? Uncovering and assessing assumptions regarding Central Himalayan medicinal plant conservation. Biodiversity and Conservation 16: 1679-1697.

[12] Liu, Z.Y. (ed.) (1992): Soils in Shanxi province. - Science Press, Beijing. (In Chinese).

[13] Lomolino M.V. (2001): Elevation gradients of species diversity: historical and prospective views. - Global Ecology and Biogeography 10: 3-13.

[14] Ma, Z.Q. (2001): Vegetation of Shanxi Province. - China Science and Technology Press, Beijing.

[15] Molles, M.C. (2002): Ecology: concepts and applications ( $2^{\text {nd }}$ ed.). - The McGraw-Hill Co., Singapore.

[16] Orians, G.H. (1993): Endangered at what level? - Ecological Application 3: 206-208.

[17] Oyonarte, C., Aranda, V., Durante, P. (2008): Soil surface properties in Mediterranean mountain ecosystems: Effects of environmental factors and implications of management. - Forest Ecology and Management 254: 156-165.

[18] Paschke, M.W., Redente, E.F., Brown, S.L. (2003): Biology and establishment of mountain shrubs on mining disturbances in the Rocky Mountains, USA. - Land Degradation \& Development 14(5) : 459-480.

[19] Pickett, S.T.A., Ostfeld, R.S.O, Shachak, M., Likens, G.E. (1997): The ecological basis of conservation, Heterogeneity, ecosystems and biodiversity. - Chapman \& Hall, New York.

[20] Pielou, E.C. (1975): Ecological diversity. - Wiley \& Sons, London.

[21] Pimm, S.L., Askins, R.A. (1995): Forest loss predict bird extinction in eastern North America. - Proceedings National Academy of Sciences U.S.A. 92: 9343-9347.

[22] Ru, W.M., Zhang, F. (2000): A study of quantitative classification of vegetation vertical zones in the eastern part of Zhongtiao Mountains. - Chinese Journal of Applied and Environmental Biology 6(3): 201-205. (In Chinese with English abstract).

[23] Ru, W.M., Zhang, J-T., Zhang, F., Zhang, G.P. (2006): Eco-environmental characteristics and endangered causes of Taxus mairei, an endemic to China. - Bulletin of Botanical Research, 26(5): 624-628.

[24] Saarsalmi, A., Malkonen, E., Piirainen, S. (2001): Effects of wood ash fertilization on forest soil chemical properties. - Silva Fennica 35(3) : 355-368.

[25] Saeki, I. (2007): Effects of tree cutting and mowing on plant species composition and diversity of the wetland ecosystems dominated by the endangered maple, Acer pycnanthum. - Forest Ecology and Management 242: 733-746. 
[26] Sajwan, B.S., Kala, C.P. (2007): Conservation of medicinal plants: Conventional and contemporary strategies, regulations and executions. - Indian Forester 133(4): 484-495.

[27] Stevens, G.C. (1992): The elevational gradient in altitudinal range: an extension of Rapoport's latitudinal rule to altitude. - American Naturalist 140: 893-911.

[28] Sun, J., Yang, F., Pang, H. (2007): Effects of shading treatment on photosynthetic response and life cycle form of Taxus chinensis var. mairei. - Bulletin of Botanical Research 27(4): 439-444.

[29] ter Braak, C.J.F. (1986): Canonical correspondence analysis: a new eigenvector method for multivariate direct gradient analysis. - Ecology 67: 1167-1179.

[30] ter Braak, C.J.F., Šmilauer, P. (2001): CANOCO Reference Manual and User's Guide to Canoco for Windows. Software for Canonical Community Ordination (version 4.5). Centre for Biometry Wageningen (Wageningen, NL) and Microcomputer Power (Ithaca NY, USA), pp.352.

[31] World Conservation Monitoring Center (1992): Global biodiversity. - Chapman \& Hall, London.

[32] Wu, Z.Y. (ed.) (1979): Flora of China. - Science Press, Beijing.

[33] Wu, Z.Y.(ed.) (1980): Vegetation of China. - Science Press, Beijing.

[34] Zhang, J-T. (2002): A study on relations of vegetation, climate and soils in Shanxi province, China. - Plant Ecology 162(1): 23-31.

[35] Zhang, J-T. (2004): Quantitative ecology. - Science Press, Beijing. (in Chinese).

[36] Zhang, J.-T. (2005): Succession analysis of plant communities in abandoned croplands in the Eastern Loess Plateau of China. - Journal of Arid Environments 63(2): 458-474.

[37] Zhang, J-T., Chen, T. (2007): Effects of mixed Hippophae rhamnoides on community and soil in planted forests in the Eastern Loess Plateau, China. - Ecological Engineering 31: 115-121.

[38] Zhang, J-T., Meng, D.P., Ru, W.M. (2007): The ecological characteristics of the endangered species Paeonia suffruticosa var. spontanea in China. - Natural Areas Journal 27: 145-154.

[39] Zhang, J-T., Oxley, R. (1994): A comparison of three methods of multivariate analysis of upland grasslands in North Wales. - Journal of Vegetation Science 5: 71-76.

[40] Zhang, J-T., Ru, W.M., Li, B. (2006a): Relationships between vegetation and climate on the Loess Plateau in China. - Folia Geobotanica 41: 151-163.

[41] Zhang, J.-T., Xi, Y., Li, J. (2006b): The relationships between environment and plant communities in the middle part of Taihang Mountain Range, North China. - Community Ecology 7(2): 155-163.

[42] Zhang, J-T., Zhang, F. (2007): Diversity and composition of plant functional groups in mountain forests of the Lishan Nature Reserve, North China. - Botanical Studies 48: 339348. 